\title{
Schooling across Contexts: The Educational Realities of Old Colony Mennonite Students
}

\author{
Wendy Crocker ${ }^{1}$
}

Assistant Professor

Faculty of Education

University of Western Ontario

\begin{abstract}
This paper narrates the schooling experiences of the Old Colony Mennonites (OCM) across two contexts based on my first-hand observations as a principal in a rural, southwestern Ontario school and on a research trip to the Cuauhtémoc, Chihuahua State, Mexico. The OCM children described in this paper attend public school in southwestern Ontario and travel regularly to Mexico where many of the families hold property or visit family. Thus, during one calendar year, these OCM children often attend schools in two countries with differences in the use of language(s) and literacy practices, expectations in the classroom, and even the meaning of playing outside. This reality, which requires OCM students to adapt to the expectations of two very different learning cultures, is an important facet in the life of these children, whose experiences of school and education are vastly different. Using ethnographic methods and case study tools including photos, I describe the educational settings of Ontario and Chihuahua where OCM students are schooled. Further, I illustrate how the diaspora from Russia to Manitoba, Canada; the subsequent migration to Mexico; and then the return of the OCM to Canada (this time Ontario) was partially predicated on the need to find places where their beliefs about education could be enacted, a search that continues to the present.
\end{abstract}

\section{Keywords}

Old Colony Mennonites; literacy; schooling; assessment; Ontario; Manitoba Colony, Chihuahua, Mexico

\section{Acknowledgements}

Thank you to the OCM children and their families in southwestern Ontario, from whom I continue to learn so much. I would also like to acknowledge the members of the Mennonite Community Services in Aylmer, Ontario, and the service providers who come together as the members of the Low German Networking Committee for their tireless efforts to build bridges of understanding and acceptance. 


\section{Introduction}

The purpose of this paper is to discuss the schooling experiences of children from the Old Colony Mennonites (OCM) across two contexts: in Southwestern Ontario public schools, and in the schools on the campos, or villages, of Chihuahua, Mexico. My ethnographic account is based on my experience as an "edgewalker" (Krebs 1999), a non-Mennonite elementary principalresearcher who has worked among this ethnocultural group for well over a decade. As I walked the line between the educational expectations and practices of the dominant culture and the OCM, I came to realize that the children often attended two schools, in two different countries, with significant differences in relation to the use of language(s) and literacy practices, expectations in the classroom, even to what it meant for the children to play outside. This reality required the OCM students to adapt to the expectations of two distinct learning cultures and is an important facet in the life of these children, whose experiences of school and education are vastly different. Further, I narrate how the visible representations of school and schooling for these children in two contexts is predicated on understandings of the purpose of education, the value of language, and what it means to be an Old Colony Mennonite.

\section{The Narrator's Context}

Ontario is a province with vast cultural and linguistic diversity. Original settlers to the area arrived from England, Scotland, and Ireland and were joined after 1776 by Americans who were still loyal to the British government. During the 1800's, more settlers arrived from Europe en route to Manitoba and Alberta but often chose to stay in Ontario with its rich agricultural land. In $1901,57 \%$ of the population of 5,371,315 claimed British citizenship (Robertson 2012). Eventually, 1,300 Mennonites entered Ontario, largely from Mexico (Dench 1999). While this begins to paint a picture of the large numbers of Low German speaking Mennonites ${ }^{2}$ in the province, the actual population is not accurately captured by government census counts (Figure 1). The Old Colony Mennonites are just one of a number of Mennonite orders that call Ontario home.

While several generations have now come to the rich agricultural land along the northern shores of Lake Erie in Ontario, their adherence to the strict laws of the Gemeinde (group of believers) warns against interaction outside the Mennonite colony. The cultural imperative coupled with a mistrust of the government precludes many from taking part in census taking. However, inhabitants of rural southwestern Ontario are well aware of the large numbers of Mennonite families who are residents between the April asparagus harvest and the October picking of apples before they return to their homes around Chihuahua, Mexico. The prevalence of Low German or Plaudietsch speakers in southwestern Ontario should make this oral language recognized by English speakers, as yet another language to add to the mix. However, it is rarely recognized by those outside communities where LGM reside and work. 


\section{Figure 1: Old Colony Settlements in Ontario}

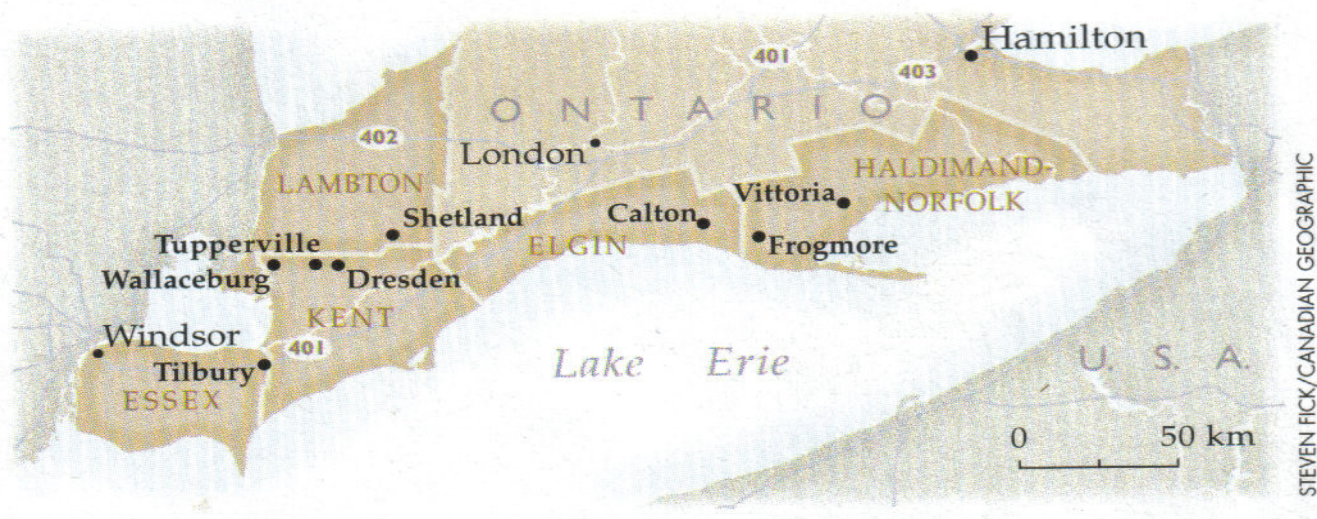

Used with permission

Into this context I arrived as a newly minted vice-principal. In my personal journal, I recorded my first interaction with the LGM children,

Today the buses pulled into the school parking lot and disgorged themselves of excited schoolchildren. I saw blonde-haired children in dress reminiscent of Little House on the Prairie with the girls in home-made print dresses and the boys in plaid shirts, denim coveralls and straw hats. They smiled shyly as they walked past me and whispered among themselves in a language that was unfamiliar to me.

The language, I discovered, was Plautdietsch and these children became more than a cultural footnote within my administrative responsibilities first as vice-principal, then later as an administrator in a 400-student primary school. During my tenure as principal, I was to come to learn the rhythms of the Old Colony students' attendance at school — their annual pattern of arriving in May and leaving again in autumn, a reflection of the crops in which they were employed as seasonal workers. They disappeared overnight, their family members and belongings packed into a van returning to their property in Mexico. My curiosity about their school life in their time away from Ontario grew with each year that I worked among these children (Crocker 2013a).

\section{The Old Colony Mennonite Context}

The OCM are one of three branches of the Low German speaking, conservative denomination of Mennonites (Reimer 2008). When thought of as a continuum, the most liberal are those of the Kleine Gemeinde, followed by the Rheinlander, with the Old Colony being the most conservative or orthodox in its adherence to the teaching of the Lutheran Bible. In each of these Low German speaking Mennonite branches, the bishop is responsible for interpreting the Bible and determining how it is to be enacted in everyday life-wisdom he in turn shares with the ministers in each Gemeinde (Crocker 2013b). As a continuation of the church hierarchy, the 
bishop uses the ministers to enact his decisions about the many forms of activity in the colony, from what is acceptable women's work (Epp 2008) to how farming will be conducted by the colony, through to issues related to education and the language of instruction in the village schools (Redekop 1989; Roth 2011).

For some time now, members of the OCM have experienced the tensions of living a transnational life. Their founder, Menno Simons, preached the need for adult baptism and pacifism from his literal translation of the Lutheran Bible. The oole Ordnunk (Ordnung) or unwritten code by which the OCM live (Hedges 1996) is based in part on Simons' teachings. Central to his vision was the ability of his followers - now the Mennonites - to live a life on earth that prepared them for the life everlasting but only as a member of the Gemeinde. Salvation was, in accordance with the Ordnung, given to the group and not the individual. Thus, life on earth was tied directly to the Gemeinde and afterlife. This adherence to Gemeinde on earth for salvation in heaven is a key tenet in the Mennonite faith and is foundational to understanding the transnational nature of the OCM. Not only does the Gemeinde require large tracts of land to settle as a colony and a place to practice their religion without persecution but also a location where they can be free to establish their own education system with High German as the language of instruction (Crocker 2013a).

\section{Education and Schooling}

Education and schooling have always been a concern of the LGM. OCM schools in Manitoba were replicas of the successful schools from Russia-a curriculum based on fundamentals of reading, writing, and arithmetic using the Bible as the text. Instruction in High German ensured that at their $14^{\text {th }}$ birthday students would leave school prepared to become good Mennonites - that is, members of the colony through baptism at age 18 into the Gemiende. Although their schoolhouse education would be over, a scholar's education would continue at home under the tutelage of their same-sex siblings and parent as a gendered apprenticeship (Rogoff 2003).

Schooling has been at the root of much of the historical migration of the LGM since coming from Russia to the Western hemisphere in 1874. Following WWI, fear of conscription and a rise of patriotism in Manitoba caused a series of acts of parliament to be passed that pushed up against the negotiated rights of the Mennonites to manage their own schools in German apart from the provincial, English schools. As a result, the OCM sought other places to settle and eventually migrated from Manitoba to northern Mexico in 1922. Under the Privilegium signed by Mexican President Alvero Obregon, the Mennonites were again promised freedom from religious persecution and the ability to organize, build, and run their own schools using German as the language of instruction (Crocker 2013b) 


\section{Schooling in Ontario}

My experience working with OCM students and their parents as an administrator for almost a decade offered me an interesting lens through which to observe their beliefs about education and approaches to school. Given that many of the children attended schools in southwestern Ontario and then schools on the campos of northern Mexico, I wondered if my experiences were echoed by other school principals and vice principals. I conducted my dissertation research with a Principal Learning Team comprised of the administrators from several schools within the same jurisdiction, whose school demographics were similar to my own - that is, a large population of first and second generation OCM whose first language was Low German. We met regularly to share narratives of our lived experiences working with these children and their parents, and what emerged were striking similarities about the disconnect between the schooling of these children and how education is enacted in Ontario. Chief among these was the mismatch between the literacies of the OCM children and the large scale, Education Quality Accountability Office (EQAO) assessment.

\section{The Role of Large Scale Assessment}

Late in the 1990s, the Province of Ontario introduced standardized testing for all students at the grade three and six levels (Education Quality and Accountability Office Act 1996). The EQAO test consisted of several days of pencil-and-paper testing of the cumulative skills expected by the Ontario curriculum with a focus on language and mathematics. The rules for participation were rigid: every child was obliged to write the test unless a legitimate reason not to could be legally shown. Students on Individual Education Plans (IEP) or those children new to Canada receiving English as a Second Language (ESL) support were exempted. Because the test was initially publicized as a tool to monitor the success of the new curriculum introduced by a Conservative government in the late 1990s (see http://www.eqao.com/pdf_e/12/PowerOntProv TestingProg_en.PDF), the students who were exempted were figured into the school result by counting their score as zero. Those neighborhood schools that had large numbers of students from newcomer families or schools that served populations of children on IEPs had school-wide scores that were significantly reduced across all assessment areas. Had the test scores remained confidential for school and board use, the impact may not have been significant. However, individual school results were posted in order of rank in the local papers. Overall system scores were reported in relation to the scores of other area school boards. Now, almost two decades later, even with several major changes to the format, duration, and focus of the assessments, the EQAO tests are still cause for concern for teachers and administrators. Within the context of Ontario education, it is tacitly understood by school officials that if a student scored at a Level 3 (B), then that pupil is considered to have met the provincial standard, which defines what it means to be literate.

In my school, with its large population of OCM who were transnational in nature and who arrived weeks before the assessment, EQAO was a huge strain. We could not predict the 
arrival of the children, nor could we anticipate who would be writing the test. We had worked hard with LGM parents so that they would understand the importance of attendance at school for children until the age of 18 while in Ontario, so asking the children to stay home during the assessment was neither ethical nor possible. Instead, children at grade three (aged eight years) were seated in desks with other eight-year-olds, unspeaking, and confronted by a pencil-andpaper test in a language that they could neither read nor write. In my dissertation data, Teresa, a principal colleague observed,

I think that if we didn't have EQAO, we would be very happy. What happens is that the kids come in, and the kids come out, and every year about now we get a bunch back, or we will get more, and they haven't had any practice since school in October in EQAO, you know what I mean, because they don't fit any of the criteria to exempt [...] a lot of them know enough that they have to write it but, I am going to use the word discouraging - it is discouraging [...] teachers work so hard and all of a sudden two kids show up two weeks before [the test] and now they are on EQAO (Crocker 2013a, 128).

More frustrating than the reality of the EQAO assessment is the mismatch between the expectations of the test and my understanding of the literacies with which these OCM children came to school. In viewing literacy as more than simply reading and writing but rather as multiple means of making meaning (New London Group 1996), I could name several languages and many ways in which the LGM student were literate: in understanding and speaking Spanish, in understanding and speaking Low German, in some understanding and some communication in High German (depending on their age), and in understanding and speaking some basic English. What was missing from their repertoire was writing of any language. I was puzzled by this until I understood that Plautdietsch is very dialectic and differs according to geography. The dialect learned by children in Mexico or Belize, for example, can be distinguished from that learned in Manitoba or Russia. While dialectic differences may make it difficult to have a fluent conversation, it becomes even more challenging when trying to capture Low German in written form. Many of the members of the LGM community haven't seen the language that they routinely speak as a written text. Among the Low German-speaking Mennonites in Ontario, English, Plautdietsch, and High German are used by different members of the community, for different purposes, and at different times. Because LGM families have roots in Mexico or other parts of Latin America and because many continue to travel back and forth, Spanish is also added to the mix of languages in use. The demands made upon LGM children who participate in at least two very different cultures and discourse communities (Swales 1998) are significant. For these children, acquiring literacy "is a complex business involving several languages" (Gregory and Williams 2000, 167). As noted by Luke and Kale (1997), "the products and constructions of the complex and diverse social learning from the culture(s) where children grow, live and interact" (16) are representative of multiple literacies and ways of knowing. When LGM children arrive at public school in southwestern Ontario, many bring this plethora of literacies with them 
but lack the one that is counted in the Ontario context: proficiency in school literacy, reading and writing in English.

\section{Being “in" School}

My personal journal is replete with stories about OCM children adapting to schooling in Ontario. Girls, dressed in their traditional homemade dresses, with white ankle socks and carefully plaited hair, would often bring small dolls or toys to play with at outside recess. Rarely would they join in the running games of the OCM boys, who were disappointed to learn that in the schools in our jurisdiction, baseball was not played at recess because of threat of injury. Instead, they ran. And ran. And ran. They were always on the go, inventing games of tag, games with a ball, or soccer-like games that they learned from their Ontario peers. The boys were always wearing hats - usually a ball hat sporting the logo of farm equipment or plain in color, unlike the hats of their colleagues that colorfully displayed the logo of a favorite sports team. When inclement weather meant indoor recess, while the girls dutifully colored or drew, the boys struggled to contain their energy with these small motor tasks (Figure 2).

In Ontario, the public schools are housed in large, climate-controlled buildings with air conditioning, bright overhead lighting, and large windows to the outdoors. There are colorful displays on the walls. Children are divided into grades according to their age, and each grade has their own classroom. Classes are rarely together with other classes unless it is an assembly of the whole school or another special event. Within their classrooms, children often work at desks that are grouped together to form pods for conversation and shared problem-solving. They move to a carpet for large group time with colorful books read aloud by the teacher, or to interact with the electronic Smartboard ${ }^{\complement}$ to solve mathematical problems or engage in reading or writing activities. Students travel the hallways in quiet-ish lines to the gym, to the library, and to the music room. School is a bright, vibrant, often noisy, collaborative space.

I recall an OCM child coming to school on her first day. I was stationed at the front door and greeted her mother in my halting Low German. She smiled. I crouched to welcome her daughter who had stopped, abruptly, inside the main doors. Her eyes darted between her mother and I, and then to the busy, colorful hall behind me that was filled with chatting, bustling children. I took tears as a signal of her reluctance to leave her mother and come to school. However, after visiting the schools in Northern Mexico - schools that many of the children from my Ontario school attend when they are living on the campos - I believe that I may have misunderstood what she was communicating. While I was conditioned to one way of schooling, the OCM children experienced two very different contexts often within one calendar year. In the next section of this paper, I will retell my experience visiting schools in Northern Mexico, walking in the footsteps of some of my students. 


\section{Figure 2: OCM Children in an Ontario Classroom}

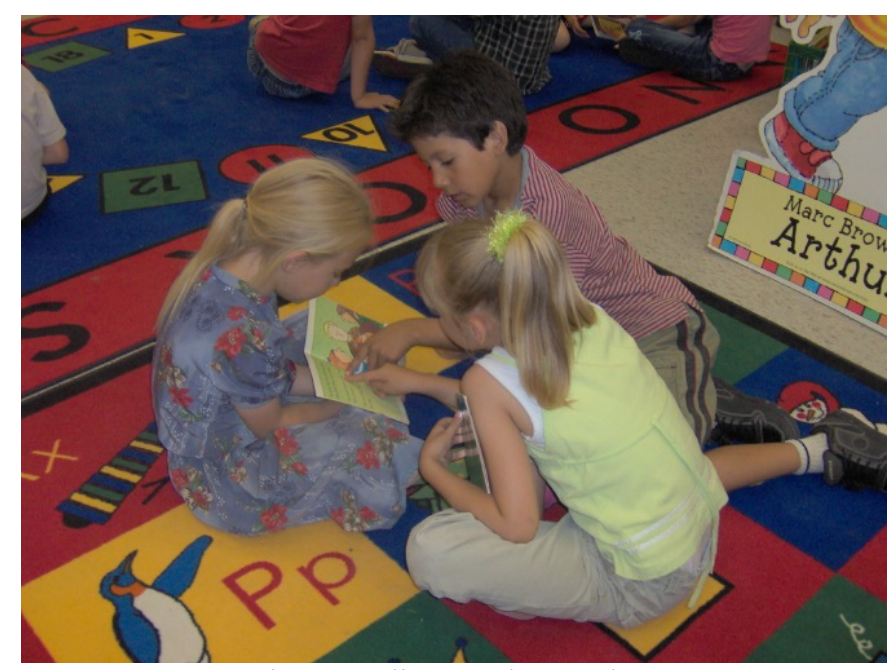

Photo credit: Wendy Crocker

\section{Schooling in Mexico}

My visit to the Cuauhtémoc area, Chihuahua State in northern Mexico in 2012 was a pilgrimage of sorts. I felt that, as an administrator of a school in Ontario that served a large number of OCM students and their families, it was incumbent upon me to learn more about where the children were educated when they weren't at my school. What did that school look like and how was it organized? What were the instructional practices? What languages were taught and used, and what was the role (if any) of English? I looked forward to following the journey of some of my students and their families that I hoped would lead to my deeper understanding of OCM schooling and education.

My first surprise was the realization that Old Colony schools in Mexico did not operate in one, single, accepted manner. Every child in the colony was entitled to attend school. Where the choice was not "either attend school or stay at home and work," I became aware of several layers of schooling in Mexico, each in direct relation to Old Colony faith orthodoxy. All schools were funded and run by Mennonites with a male Board of Trustees to oversee the hiring of the teacher and the governance of the school. All children could attend a Mennonite-run school, from the free, local village school to the fee-paying, more liberal Alvaro Obregon school, celebrated throughout the area for having many of its high school scholars enroll at the University of Chihuahua. I was astounded to discover that there was no need for an attendance counselor to round up truant students as there was in Ontario. On the colony, each family, each child understood that according to the Ordnung, they were mandated to attend school to learn the prayers and catechism expected in the Old Colony Church. School was a traditional practice to learn to be a good Mennonite. 


\section{Dorf Schools}

The schools that are the most traditional (i.e. in keeping with the Ordnung, the way in which the Mennonite forefathers would have experienced) continue to be those of the Old Colony and are known as Dorf - or "village" — schools, run according to the "old system" (David F., personal communication, March 15, 2012). Mennonites view school as the bridge between the secular and sacred realms and as the completion of the socialization of children that was started in the home (Crocker 2013c). Literacy is the tool through which the children learn the Katechismus (catechism and the 18 articles of faith) and hymns (Gesangbuch). As my ministerguide, David, explained, in Dorf schools, the children are divided as they would be as adults in church, with boys on one side and girls on the other. The school desks are long, about ten to 12 feet in length, with a backless bench for seating, the same type of bench seating that would be found in an Old Colony church. Much of the curriculum was taught by rote and is focused on reading, writing, and arithmetic. Reading was done in High German from the Lutheran Bible and related Bible stories, and all instruction is by recitation. The only decoration on the bare walls was a clock and the chalkboard, which is on the wall behind the teacher's desk. Writing was the traditional, High German gothic alphabet, and the children practiced on slates using chalk. Basic sums, subtraction, multiplication, and division were addressed from shared textbooks or in word problems the teacher created. School begins at age seven (Fibler) and is finished at age 14 (Bibler), when the girls continue their education at home under the tutelage of their older, samegender siblings and mother. The boys work with their fathers and older brothers on the farm or learn a trade as an apprentice. There are no report cards (Verhaltniskarten), so progress is noted by the book from which each child's lessons are taken, beginning with the Fible; moving through the New Testament, Katechismus, and Gesangbuch; and ending with the Bible (David F., personal communication, May 10, 2012).

The Old Colony Mennonites are the most conservative in their beliefs, adhering to the adage "school and church should be in keeping with the principles of our forefathers" (Hedges 1996, 121). The sole purpose of schooling is to give the children the literacy tools that they need to become members of the Old Colony Mennonite Church. After they finish school, they may attend church but must wait until they are 18 years of age to choose to join the church through adult baptism. Only those who are baptized may be married in an Old Colony church.

\section{Connecting Church and School}

My pastor-guide took me to several different types of Old Colony Mennonite schools. While each school was rooted in the same purpose of education (i.e., preparation to become a good Mennonite), there were significant differences in the purpose of schooling (i.e., enough basic skills to be a good Mennonite or education for an English world) and the use of either High German or Low German as the language of instruction. These contradictions in educational purpose and language hierarchy were presented as a deeply rooted struggle of faith. While Old Colony committee schools maintain the intent and legacy of their forefathers (i.e., according to 
the Ordnung, "it is the way in which it has always been done"), more and more emphasis has been placed on Low German as the language of conversation. As a result, High German has been relegated for use only when in church, to the chagrin of many bishops, ministers, and elders. Bishops and ministers still preach only in a homogenous sounding High German. The hymns are led by a vorsanger and are sung, unaccompanied, in the traditional chant-like style in High German. As I was told by an adolescent Reinlander woman, more and more Old Colony Mennonites are expressing a lack of comprehension of what has been preached in church (Carolina P., personal communication, June 5, 2011). Some pastors preach in High German then editorialize the sermon by explaining it in Low German. However, this occurs infrequently, and as a result, the young people are choosing to join more progressive churches, such as the Kleine Gemeinde and the Reinlander. The loss of congregational members is of great concern to the Old Colony elders, and they recognize that the way to make change is with the children who are not yet church attendees. This intervention will also entail changing the teaching and learning (i.e., curriculum) at the Dorf schools.

\section{The "Committee" Schools and the "New System"}

With the election of a new bishop in Cd. Cuauhtémoc in early 2000, there has been an increased focus in schools on the teaching, and understanding, of High German. This evolution in teaching methodology has been referred to as the New System. To help to make the transition, for the last decade, the Old Colony elders have secured the assistance of Amish teachers from Ohio. In a book by the Old Colony Mennonite Support (2011), Called to Mexico, many of these teachers share their narratives about teaching the children in the Manitoba Colony in Mexico.

The committee school was surrounded by an adobe wall, and the playground was flat. Dusty, red earth extended everywhere the eye could see, with no playground equipment, soccer goal posts, or baseball diamond. The school itself was a non-descript, grey, single floor, concrete building that didn't even display the name of the school over the door (Figure 3). The committee schools in Mexico had no outside play equipment or climbers, only a vast, sandy area that was perfect for playing baseball. Along the hallways were rows of hooks filled with wide-brimmed straw hats, ball hats, and baseball gloves (Figure 4).

As I approached the front door with two of my colleagues, I could hear prayers being chanted in unison in a sing-songy way, just as I had heard them being prayed in an Old Colony church on the previous Sunday. We entered the front door, and I was immediately struck by the openness - sunshine glinted through the windows and reflected off the sparkling clean floor. Ahead of us was another exit, with the boys' and girls' washrooms on opposite sides of the main hallway. The doors were open to reveal modern, stainless steel sinks and toilets. The small office adjacent to the washroom was the teachers' room, which housed the mailboxes for staff members as well as the photocopier. Beyond the copier and through the window in the top half of the closed door we could see the principal's office. The office was empty, however, as the principal waited to greet us in the hallway with a handshake and a warm smile. 


\section{Figure 3: Old Colony Committee School in Cd. Cuauhtémoc, Mexico}

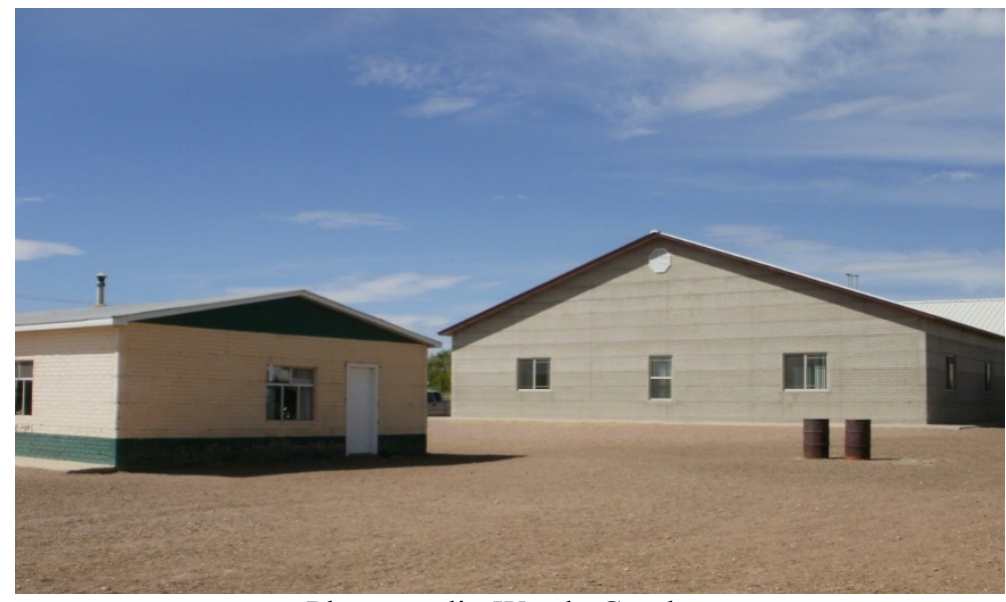

Photo credit: Wendy Crocker

\section{Figure 4: A Row of Children's Sunhats and Baseball Gloves Line the Halls of a Committee School}

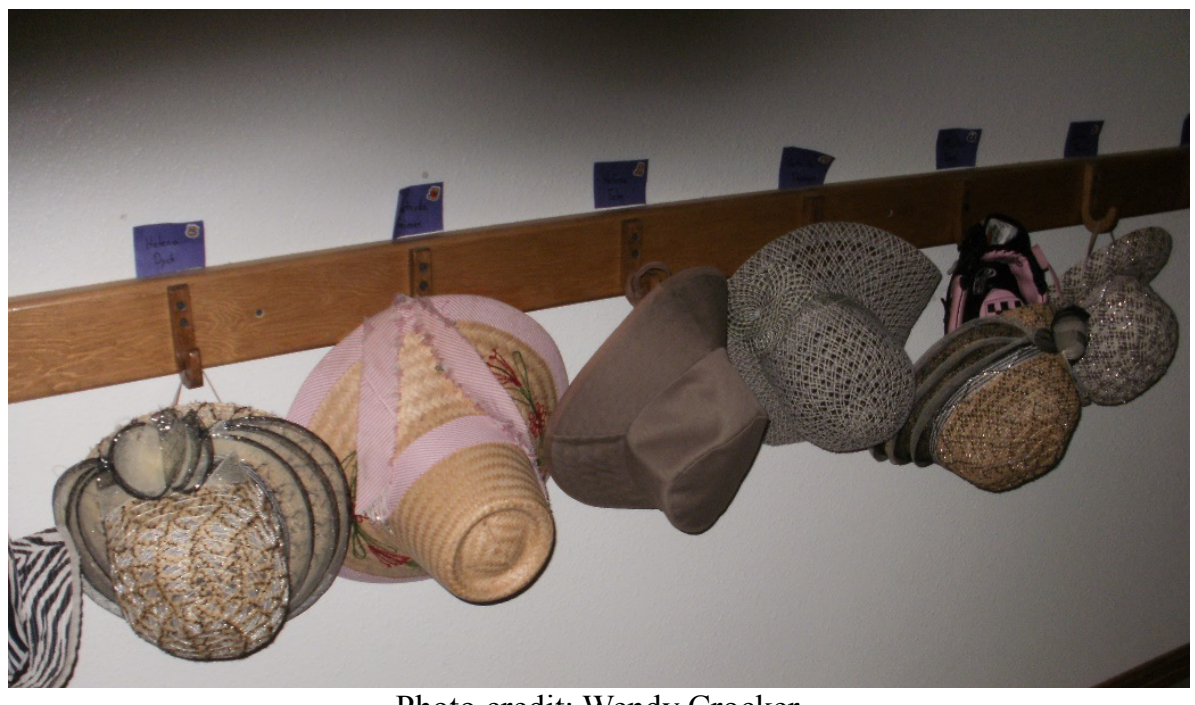

Photo credit: Wendy Crocker

In my halting Low German - and with the assistance of our minister interpreter-I was able to gather that the principal was the only male on staff. He was a graduate of the school when it had been the Dorf school for the two local villages. On our tour, it seemed he was pleased with the conduct of the children as they greeted us in each classroom and then allowed us to sit in for parts of the lessons. As my eyes wandered around the Fibler's (i.e. age seven) classroom, I noticed that I was being furtively watched by the children under half closed eyelids. I would wink and they would shyly smile in return and quickly return to their work. The classroom had two teachers, one as teacher and the other as assistant. Both women were Mennonite. This was the children's first year of school and they were seated in individual desks with a side slot for 
holding books and pencil cases. I whispered to the teacher closest to me and asked if I could walk around and see the children's work. She blushed, but after a hurried conversation with the principal, I was assured that it was fine.

The children were busy on a combination of consumable worksheets that addressed the letter "Vv." Some of the students were doing dot-to-dot to create a large "v" complete with a small picture of a vase that could be colored later. Others were practicing alphabet letter formation from A to $\mathrm{Z}$. I whispered to the translator to inquire why the children were learning the English alphabet. He grinned and explained that the High German alphabet can be written in two ways: the Latin form and the Gothic form. The Latin form looks very similar to our alphabet. I smiled to myself and wondered if the comfort that the Mennonite children in primary classes in Ontario derive from these same kinds of "circle, color, and cut" reproducible pages was the echo of a familiar practice here in Mexico.

I scanned the classroom walls. Unlike the Dorf school, this classroom had brightly colored charts on the walls denoting birthdays and incentive charts with happy face stickers. There were hand created charts that were specific to the language being taught that varied among High German (in its Gothic version), some Low German, and a sprinkling of Spanish. The principal explained that the children were taught aloud using Low German until after the New Testament. I was puzzled, but soon learned that instead of grades, the children progressed through different biblical texts and this was how their classes were defined. Thus, the "scholars"- as the children in the school were called - are introduced to High German as the language of church through stories the teacher read aloud. The stories were discussed in Low German to ensure understanding. By the New Testament, more and more of the instruction, reading, and writing was done in High German. By Bibel (i.e. age 14), all instruction and conversation were conducted in High German - even on the playground. The introduction and use of church texts and liturgies in the school setting reinforces the OCM belief that the purpose of education is to become a "good Mennonite." School children hear the same prayers, lessons, and tenets of faith in school that they will memorize as the catechism required to join the church as teenagers and before their marriage.

Rudimentary Spanish was introduced at the upper level as a nod to understanding the context in which the children lived and could work. Mexico, after all, is a Latin American country where the majority of people are Spanish speaking. This is counter to a tenet of the Ordnung that admonishes the use of other languages (Hedges 1996). Interestingly, although many of the children in my Ontario school had attended this Cuauhtémoc committee school, there was no English language instruction as part of the curriculum.

\section{One Child, Two School Lives}

The purpose of this paper was to examine the dual contexts of schooling that are experienced by the Old Colony Mennonite children. The dichotomy that exists in the experiences 
of the same children between their school attendance in southwestern Ontario and in Cuauhtémoc, Mexico, equated to two, distinct school lives. During one calendar year, a LGM child could attend two schools in two different countries with significant differences in relation to the use of language(s) and literacy practices, expectations in the classroom, and even the ways in which children played outside.

In examining the transnational schooling experiences in the life of Low German-speaking Mennonite children, it has become apparent that educators in Ontario schools need to better understand the historical and liturgical importance of education to those in the Old Colony. While the ways in which children are educated on the campos differ according to the schools, underpinning the choice of school is the level of adherence to the Ordnung by their parents: the more orthodox the belief in the Ordnung, the more traditional the school, such that school choice becomes an outward demonstration of religious belief. However, in Ontario, it is the children who must adapt to a provincially mandated and tested curriculum that does not account for the literacies and "funds of knowledge" (Moll, et al. 1992) with which the children arrive at school. In an ethnocultural group often characterized by its adherence to "the way in which our forefathers did it," I suggest that the children of the OCM are the bridge between tradition, as represented by the Mennonite schools in Cuauhtémoc, Mexico, and the twenty-first century curriculum of Ontario's schools.

In conclusion, I return to the story of the young girl on her first day of school in Ontario. As she stood in the busy hallway gripping her mother's hand, I thought her tears were because of a reluctance to leave her mother and go to school. Knowing what I do now about the dichotomy of experiences of OCM children, the differences in literacies, school structures, curriculum, and even play, I wonder if her tears were those of confusion and a desperate attempt to make meaning of what this school was like. Certainly, it was different from school in Mexico.

One child, two school lives; if only I had known.

\section{Endnotes}

${ }^{1}$ Contact information: Wendy Crocker, PhD, Faculty of Education, Western University, 1137 Western Road, London, Ontario, Canada N6G6G7; wcrocke@uwo.ca

${ }^{2}$ For the purposes of this paper, Low German-speaking Mennonite (LGM) refers to Old Colony Mennonites who speak Low German or Plautdietsch as a first language and often migrate between areas in southwestern Ontario and their colonies in Mexico.

\section{References}

Crocker, Wendy. 2013a. Telling Tales out of School: Principals'Narratives of the Relationship between School Literacy and the Home Literacy Practices of a Minoritized Culture. Doctoral dissertation in educational studies. London, ON: University of Western Ontario. 
Crocker, Wendy. 2013b. "More than A,B,C: Old Colony Mennonites and the Challenges of Ontario Public Education School Policy.” Transnational Social Review 3(2):193-210.

Crocker, Wendy. 2013c. “"Home' Schooling.” Pp. 142-161 in Mothering Mennonite, edited by Kerry Fast and Rachel Epp Buller. Bradford, ON: Demeter Press.

Dench, Janet. 1999. “A Hundred Years of Immigration to Canada, 1900-1999.” Canadian Council for Refugees. Retrieved May 15, 2016 (http://ccrweb.ca/en/hundred-yearsimmigration-canada-1900-1999).

Education Quality and Accountability Office Act. 1996. Retrieved October 27, 2012 (http://www.e-laws.gov.on.ca/html/statutes/english/elaws_statutes_96e11_e.htm).

Epp, Reuben. 1999. The Story of Low German and Plautdietsch: Tracing a Language across the Globe. Hillsboro, KS: The Reader's Press.

Gregory, Eve, and Ann Williams. 2000. City Literacies. London, UK: Routledge.

Hedges, Kelly. 1996. Plautdietsch and Huuchdietsch in Chihuahua: Language, Literacy, and Identity among the Old Colony Mennonites in Northern Mexico. Doctoral dissertation. New Haven, CT: Yale University.

Krebs, Nina. 1999. Edgewalkers: Defusing Cultural Boundaries on the New Global Frontier. Far Hills, NJ: New Horizon Press.

Luke, Allan, and Joan Kale. 1997. "Learning through Difference: Cultural Practices in Early Language Socialization.” Pp. 11-22 in One Child, Many Worlds: Early Learning in Multi-Cultural Communities, edited by E. Gregory. London, UK: David Fulton.

Moll, Luis, Cathy Amanti, Deborah Neff, and Norma Gonzalez. 1992. "Funds of Knowledge for Teaching: Using a Qualitative Approach to Connect Homes and Classrooms." Theory into Practice 31:132-141. http://dx.doi.org/10.1080/00405849209543534

New London Group. 1996. "A Pedagogy of Multiliteracies: Designing Social Futures.” Harvard Educational Review 66(1):60-92. http://dx.doi.org/10.17763/haer.66.1.17370n67v22j160u

Old Colony Support. 2011. Called to Mexico: Bringing Literacy and Hope to the Old Colony Mennonites. Walnut Creek, OH: Carlisle Printing

Purcell-Gates, Victoria (ed.). 2007. Cultural Practices of Literacy: Case Studies of Language, Literacy, Social Practice, and Power. Mahwah, NJ: Lawrence Erlbaum Associates.

Redekop, Calvin. 1989. Mennonite Society. Baltimore, MD: Johns Hopkins University Press. 
Reimer, Margaret. 2008. One Quilt, Many Pieces: A Guide to Mennonite Groups in Canada. Waterloo, ON: Herald Press.

Robertson, Deborah. 2012. Canadian Immigration: Early 1900s. Retrieved May 15, 2016 (http://www.british-immigrants-in-montreal.com/canadian-immigration-early1900s.html).

Rogoff, Barbara. 2003. The Cultural Nature of Human Development. Oxford, UK: Oxford University Press.

Roth, John. 2011. Teaching that Transforms: Why Anabaptist-Mennonite Education Matters. Scottdale, PA: Herald Press.

Swales, John. 1998. "The Concept of Discourse Community." College Composition and Communication 49(2):21-32. 